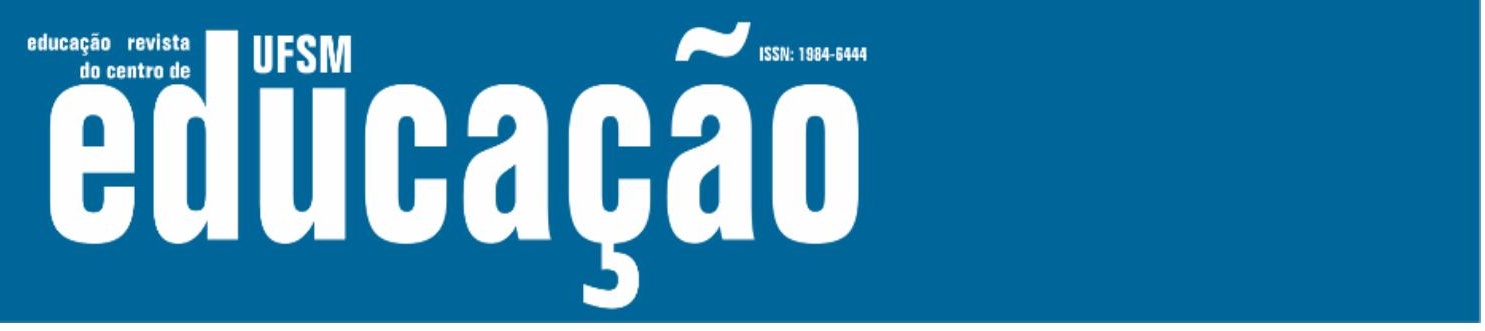

ISSN: 1984-6444 | http://dx.doi.org/10.5902/1984644466423

\title{
Digital competence of teachers and students in Yakutia: problems and prospects of e-learning during the pandemic
}

Competência digital de professores e alunos em Yakutia: problemas e perspectivas do e-learning durante a pandêmica

Maksim Anatolyevich Sorochinsky

M. K. Ammosov North-Eastern Federal University.

maksimsorochinsky@yandex.ru - http://orcid.org/0000-0002-4651-3384

Recebido em 24 de junho de 2021

Aprovado em 26 de agosto de 2021

Publicado em 30 de setembro de 2021

\section{RESUMO}

Sob medidas de auto-isolamento e quarentena durante a pandemia COVID-19 em 2020, o ensino à distância é urgente em todos os níveis educacionais. Esses eventos afetaram a competência digital de professores e alunos de especialidades pedagógicas que lecionam para alunos e escolares. $O$ artigo analisa as competências digitais necessárias para um professor moderno implementar com sucesso as necessidades educacionais dos alunos ao usar tecnologias de ensino à distância e elearning. $O$ objetivo da pesquisa é aumentar o nível de competência digital, avaliando esse nível e identificando problemas na utilização do e-learning. O estudo foi realizado por meio de um questionário desenvolvido pelo centro analítico da Agência Nacional de Pesquisas Financeiras (NAFR) Russian Teachers 'Digital Literacy, permitindo a identificação das principais competências exigidas para um professor moderno, como atuar em ambientes de ensino à distância, conhecimentos sobre a noções básicas de tecnologias de nuvem e a capacidade de organizar a interação online e offline, usando vários serviços. De acordo com o cálculo do coeficiente de concordância de Kendall, foi feita uma classificação dos lados positivos e negativos identificados na organização da interação remota entre professores e alunos da República de Sakha (Yakutia) durante a pandemia. Os resultados do estudo permitiram aumentar a eficiência do trabalho com alunos e professores e organizar cursos de atualização e apoio na implementação do e-learning.

Keywords: Competência digital; E-learning; Pandemia. 


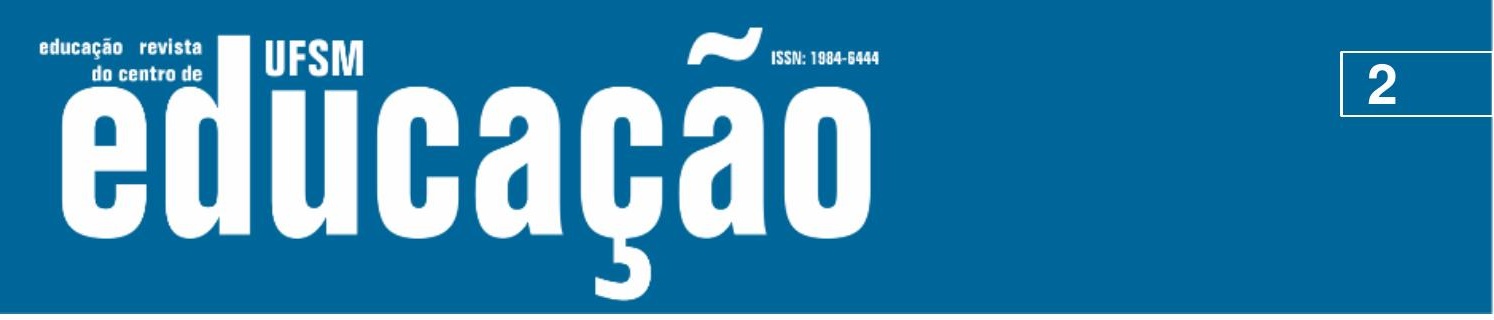

ISSN: 1984-6444 | http://dx.doi.org/10.5902/1984644466423

\begin{abstract}
Under self-isolation and quarantine measures during the COVID-19 pandemic in 2020 , distance learning is urgent at every educational level. These events affected the digital competence of teachers and students of pedagogical specialties who teach students and schoolchildren. The article analyzes the digital competencies required for a modern teacher to successfully implement students' educational needs when using distance educational technologies and e-learning. The research objective is to increase the level of digital competence by assessing this level and identifying problems in the e-learning usage. The study was carried out through a questionnaire developed by the National Agency for Financial Research (NAFR) analytical center Russian Teachers' Digital Literacy, allowing identification of the main competencies required for a modern teacher, such as work in distance learning environments, knowledge of the basics of cloud technologies, and the ability to organize online and offline interaction, using various services. According to the calculation of Kendall's concordance coefficient, a ranking of the plus and minus sides identified in the organization of remote interaction among teachers and students of the Republic of Sakha (Yakutia) during the pandemic was made. The study outcomes allowed increasing the efficiency of work with students and teachers and organizing refresher courses and support in the e-learning implementation.
\end{abstract}

Keywords: Digital competence; E-learning; Pandemic.

\title{
Introduction
}

The world population constantly faces certain challenges, solving which, humanity is moving forward, and this gives an impetus for the development of all spheres of human activity, new inventions, and discoveries. The COVID-19 pandemic is currently a challenge. Despite all its negative consequences, there are factors that have allowed making a distance format as a main tendency in many countries' education system during the quarantine and self-isolation. In this regard, the skills required for the organization of unimpeded contact work, using distance educational technologies and e-learning, have gained significant relevance among teachers.

In Russia, special attention is paid to the digitalization of education. The Digital Economy of the Russian Federation Program emphasizes a need to increase the awareness and digital literacy of Russians. The task is set to expand the share of the population with digital skills to $40 \%$ by 2024 (GOVERNMENT OF RUSSIAN 


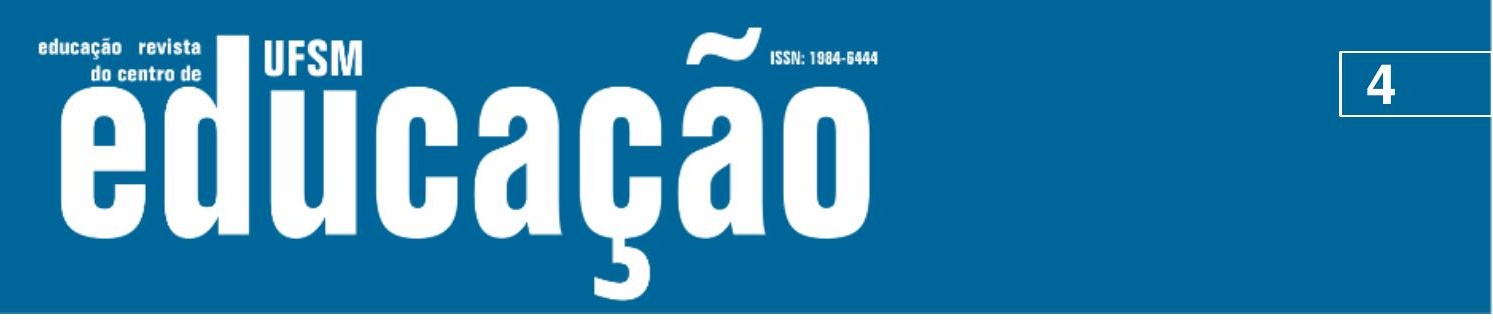

ISSN: 1984-6444 | http://dx.doi.org/10.5902/1984644466423

are learning in the digital age (BATES, 2019), the use of interactive whiteboards in teaching children with autism spectrum disorder (CATTIK, \& ODLUYURT, 2019), teaching students using a complete inverted learning (BARBER \& BLAYONE, 2018), identifying the effectiveness of using smartphones in the educational process (MAXWELL et al, 2017), integrating mobile learning in colleges (QUARLES et al, 2017), using programming languages in teacher training (PROKOPIEV et al, 2020), and using digital technologies in music education (GORBUNOVA, 2019). R.C. Clark and R.E. Mayer developed recommendations for users and developers of e-learning materials (2016, p. 507).

Also, the development of this direction has been taking place in Russia. The education informatization has been actively developing since the 90s. M.P. Lapchik considers the problem of teachers' training in the dynamically developing aspects of education informatization (2021); N.V. Gafurova pays attention to the creation of a methodology for teaching information technologies and their development (2011). There is a widespread use of the term ICT competence, considered by G.U. Soldatova as "... the ability and readiness of an individual to confidently, effectively, critically and safely choose and apply information and communication technologies to solve problems in various spheres of life" $(2015$, p. 6). Continuing research in the field of informatization and ICT competence, the aspect of digital competence is developing. So in S.M. Gushchina's work, the key role is assigned to the formation of the teacher's digital competence in digital technologies (2017).

The teacher is one of the key figures in the field of digitalization and the development of digital competencies. So in E.Z. Vlasova's research (2017), special attention is paid to the effective training of future teachers to use e-learning. Digitalization sets a new vector for the development of the northern territories, affording endless opportunities for development and communication and training specialists in pedagogy (TRETYAKOVA, 2020). Researchers have accumulated a wealth of experience in the education digitalization in the northern regions (BARAKHSANOVA, 2019), training teachers to use the elements of e-learning in the Arctic regions, the aspects of which are dealt with by E.A. Barakhsanova (2017). 


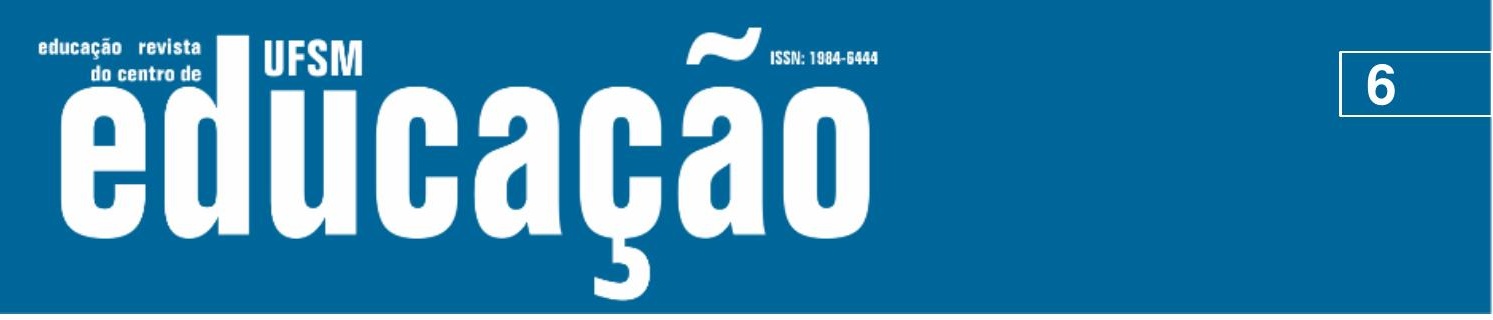

ISSN: 1984-6444 | http://dx.doi.org/10.5902/1984644466423

\section{Materials and methods}

The study involved teachers of higher and secondary vocational education and students acquiring pedagogical competence at institutions of higher and secondary vocational education. Fifty teachers to a hundred students is the ratio in the study.

At the first stage, the level of digital competence was determined applying a questionnaire Readiness to Use Digital Technologies in the Educational Process developed by the NAFR analytical center Russian Teachers' Digital Literacy (1). According to the methodology, 22 competencies are assessed, which are grouped into the following parts: 1. Professional responsibilities (16 points); 2. Digital resources (12 points); 3. Teaching and learning (16 points); 4. Assessment of students (12 points); 5. Empowerment of students' rights, opportunities and independence in the educational process (12 points); 6 . Development of students' digital competence (20 points). The maximum score for all parts is 88 points.

At the second stage, a survey was conducted, applying the method of expert assessment, to identify positive and negative experiences in the use of e-learning and elements of distance educational technologies among teachers and students of pedagogical specialties during the pandemic The respondents expressed their opinion and singled out 5 positive and negative factors, described and ranked them in descending order of importance (rated from 0 to 5 , where 0 is not important, and 5 is very important).

The results of the survey were grouped and mathematically processed to rank and check the objectivity of the data obtained. To check it and determine the consistency of opinions, Kendall's concordance coefficient was calculated with the following formula:

$$
W=\frac{12 S}{n^{2}\left(m^{3}-m\right)}
$$

where, $S$ is the sum of the squared deviations of all assessments from the mean, $n$ is the number of respondents, $m$ is the number of statements to be analyzed. The coefficient under consideration can vary in the range from 0 to 1 , where 0 is a complete inconsistency of opinions, and 1 is an absolute agreement among experts. 


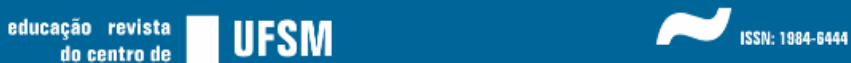

ISSN: 1984-6444 | http://dx.doi.org/10.5902/1984644466423

\section{Results}

The data in Table 1 present the assessment of the level of digital competence.

Table 1 - Assessment of the level of teachers' and students' digital competence

\begin{tabular}{c|c|c}
\hline Blocks' names & $\begin{array}{c}\text { Teachers (average } \\
\text { grade) }\end{array}$ & $\begin{array}{c}\text { Students } \\
\text { (average grade) }\end{array}$ \\
\hline $\begin{array}{c}\text { Block1. Professional responsibilities (16 } \\
\text { points) }\end{array}$ & 10 & 5 \\
\hline Block 2. Digital resources (12 points) & 6 & 8 \\
\hline Block 3. Teaching and learning (16 points) & 11 & 5 \\
\hline Block 4. Assessment of students (12 points) & 8 & 5 \\
\hline $\begin{array}{c}\text { Block 5. Empowerment of students' rights, } \\
\text { opportunities and independence in the } \\
\text { educational process (12 points) }\end{array}$ & 5 & 14 \\
\hline $\begin{array}{c}\text { Блок 6. Development of students' digital } \\
\text { competence (20 points) }\end{array}$ & 10 & 46 \\
\hline Total (Maximum 88 points): & 50 & 5
\end{tabular}

Source: own research

The average indicator of digital competence of the tested teachers turned out to be slightly higher (by $4.5 \%$ ) than that of students. However, if we analyze each block separately, we observe a slight prevalence of average scores among students in blocks 2 and 6 .

Block 1 includes: professional cooperation, reflection, communication, using digital communication, and continuous professional development in the field of digital technologies. In view of the fact that students are still in the learning process, the indicator for this level is significantly lower than that of teachers.

Block 2, digital resources, including competencies in the ability to select educational resources, create and use digital content, ensure the protection of personal data, demonstrates a slight advantage (by 8.3\%) in students. Block 6, the development of students' digital competence, shows imparting information literacy, the creation and responsible use of digital content (students' level is higher by $20 \%$ ). This may be due to the fact that students have a better command of the selection of digital materials and ensure their data protection. 


\section{Tism

ISSN: 1984-6444 | http://dx.doi.org/10.5902/1984644466423

According to the data in blocks 3 and 4, teachers have a level higher by $12.5 \%$ and $33.3 \%$, respectively. The organization of students' education, using digital technologies, including joint work and project activities, is reflected in block 3 . Block 4 includes receiving feedback, monitoring students' progress and analyzing the data obtained. Teachers have a higher level, which indicates more pedagogical experience in working with students.

All respondents have the same level in block 5 . This block shows the management of the educational process, students' involvement in it, and strengthening cognitive abilities.

The second stage revealed the positive and negative experiences in using elearning by teachers and students during the pandemic. Table 2 presents the results of calculating Kendall's concordance coefficient and ranking the identified factors.

Table 2 - Assessment of the plus and minus sides in the use of e-learning by students and teachers during the pandemic

\begin{tabular}{|c|c|c|c|c|}
\hline \multirow[t]{2}{*}{ Rank } & \multicolumn{2}{|l|}{ Teachers } & \multicolumn{2}{|l|}{ Students } \\
\hline & Factors & $\begin{array}{l}\text { Kendall's } \\
\text { concordance } \\
\text { coefficient }\end{array}$ & Factors & $\begin{array}{c}\text { Kendall's } \\
\text { concordanc } \\
\text { e coefficient }\end{array}$ \\
\hline \multicolumn{5}{|c|}{ Plus sides } \\
\hline 1 & High efficiency & 0.83 & $\begin{array}{c}\text { Availability and } \\
\text { individualization of training }\end{array}$ & 0.71 \\
\hline 2 & $\begin{array}{c}\text { Communication regardless } \\
\text { of location }\end{array}$ & 0.59 & $\begin{array}{c}\text { Communication regardless } \\
\text { of location }\end{array}$ & 0.65 \\
\hline 3 & $\begin{array}{c}\text { Availability and } \\
\text { individualization of training }\end{array}$ & 0.55 & High efficiency & 0.53 \\
\hline 4 & $\begin{array}{c}\text { Low cost and economic } \\
\text { efficiency }\end{array}$ & 0.32 & $\begin{array}{c}\text { Low cost and economic } \\
\text { efficiency }\end{array}$ & 0.3 \\
\hline 5 & Ecological compatibility & 0.1 & Ecological compatibility & 0.24 \\
\hline \multicolumn{5}{|c|}{ Minus sides } \\
\hline 1 & $\begin{array}{l}\text { The quality and complexity } \\
\text { of the development of } \\
\text { educational materials }\end{array}$ & 0.88 & $\begin{array}{l}\text { Motivation and self- } \\
\text { organization }\end{array}$ & 0.67 \\
\hline 2 & $\begin{array}{l}\text { Necessary equipment and } \\
\text { ability to work with it }\end{array}$ & 0.6 & $\begin{array}{l}\text { The quality and complexity } \\
\text { of the development of } \\
\text { educational materials }\end{array}$ & 0.6 \\
\hline 3 & $\begin{array}{l}\text { The Internet access } \\
\text { problems }\end{array}$ & 0.42 & $\begin{array}{l}\text { The Internet access } \\
\text { problems }\end{array}$ & 0.54 \\
\hline 4 & $\begin{array}{l}\text { Lack of personal contact } \\
\text { with the teacher / student }\end{array}$ & 0.4 & $\begin{array}{l}\text { Lack of personal contact } \\
\text { with the teacher / student }\end{array}$ & 0.5 \\
\hline 5 & $\begin{array}{l}\text { Motivation and self- } \\
\text { organization }\end{array}$ & 0.21 & $\begin{array}{l}\text { Necessary equipment and } \\
\text { ability to work with it }\end{array}$ & 0.27 \\
\hline
\end{tabular}

Source: own research 


\section{Ailtbarẫ}

ISSN: 1984-6444 | http://dx.doi.org/10.5902/1984644466423

\section{Low cost and economic efficiency.}

Teachers and students were unanimous regarding this factor; the calculated coefficient ( 0.32 and 0.3 ) indicates a low level of agreement. This means that this factor is not of priority importance for both groups.

\section{Ecological compatibility.}

It is at the lowest priority level. However, some respondents point out that the deforestation is reduced due to the transition to electronic format.

In this study, the most important minus sides in the e-learning use were also identified. These data are the most valuable, as they allow determining the further developmental trajectory. Let us consider the interpretation of negative factors:

\section{The quality and complexity of the development of educational materials.}

It is the most significant negative factor among teachers (0.88). They point out that every teacher must master a large number of different programs and platforms, as there is no single platform. It is necessary to prepare each lesson from a technical point of view, as well as to keep the attention of trainees remotely. Students, on the other hand, note (the second place) that the quality of materials is low, sometimes they lack clarity and interactivity, which has a great impact on the education quality.

\section{Necessary equipment and ability to work with it.}

It is much more difficult for teachers to organize the educational process without the necessary equipment, including software to prepare the materials. This factor is less significant for students due to the use of mobile devices among other things for learning.

\section{The Internet access problems.}

This factor takes the third place in both groups and has an average level of importance ( 0.42 and 0.54$)$ but demonstrates the significance of this problem. There 


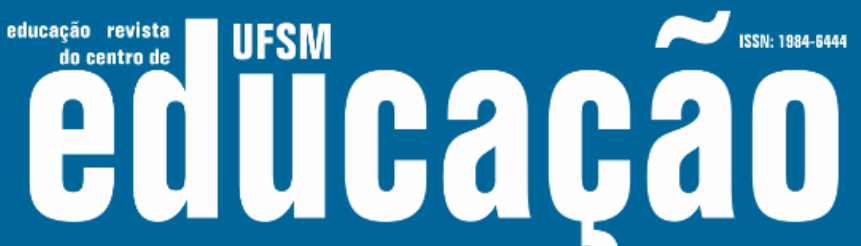

ISSN: 1984-6444 | http://dx.doi.org/10.5902/1984644466423

is an uninterrupted access to the network at the speed necessary for the transmission of video and audio information not throughout the territory of Yakutia. There are also disconnections and unstable connections.

\section{Lack of personal contact with the teacher.}

The factor is ranked fourth, but, according to the calculated coefficient ( 0.4 and 0.5 ), it has an average concordance value. From the teachers' point of view, personal contact allows monitoring the knowledge acquisition and more interaction. Students note that communication with the teacher and classmates is substantial.

\section{Motivation and self-organization.}

It ranks first among the factors among students, but the coefficient does not indicate the highest degree of agreement (0.67). During the remote work, students noted that they could not concentrate at lectures, especially since there is always a temptation to be engaged in social networks or do other things. Among teachers, the factor is not so relevant and has a weak consistency (0.21), but nevertheless it is still significant. They noted students' low motivation in online interaction and problems in enhancing their activity.

\section{Discussion}

The level of teachers' digital competence exceeds that of students dealing with pedagogical areas by $4.5 \%$. Students' results are higher in the blocks on digital resources and the development of students' digital competence. But in terms of development, it is necessary to pay special attention to the block of professional responsibilities and assessment of students.

The teachers coped well with the assignments regarding the blocks of teaching and learning and professional duties. In terms of development, attention should be paid to working with digital resources and the development of students' digital competence. Thus, teachers and students demonstrate an average level in the use of digital technologies in educational activities. 


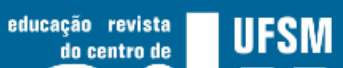 ollubará

ISSN: 1984-6444 | http://dx.doi.org/10.5902/1984644466423

When comparing the results of the study, connection is found with the all-Russian study in 2019. According to the NAFR analytical center, the index of teachers' digital competence in Russia averages 45 points; in our study this indicator is 50 points (5.7\% higher), and it equals to 46 points among students of pedagogical specialties.

A bottleneck in the study is that the assessment of the level of digital competence was carried out using one questionnaire, where all components could not be taken into account. This problem is eliminated by the chosen technique, which is certified and widely used in many countries.

\section{Conclusion}

According to the data obtained, we come to the conclusion that the teachers' and students' digital competence is at an average level, and that of teachers is even slightly higher (by 5.7\%), compared to the average results in Russia, as evidenced by the study outcomes. In addition, the experience gained in working with distance educational technologies has identified positive and negative aspects that must be taken into account when developing digital competence in the region.

The pandemic is coming to an end, but the accumulated theoretical and practical base for using the possibilities of digital technologies remains at the teachers' disposal. Due to the identified positive and negative factors related to the use of digital technologies in education, it is necessary to combine and rationally apply the gained knowledge and the accumulated experience.

Based on the data obtained, a strategy was developed to improve the digital competence in teachers and students:

- creation of a digital ecosystem;

- building an individual trajectory for the development of competencies;

- interaction with centers of education and professional development;

- participation in conferences, competitions, strategic sessions and other skill development events.

The main stages for the development of digital competence should include: assessment of the competence level; the professional development process support; and training and professional development. 


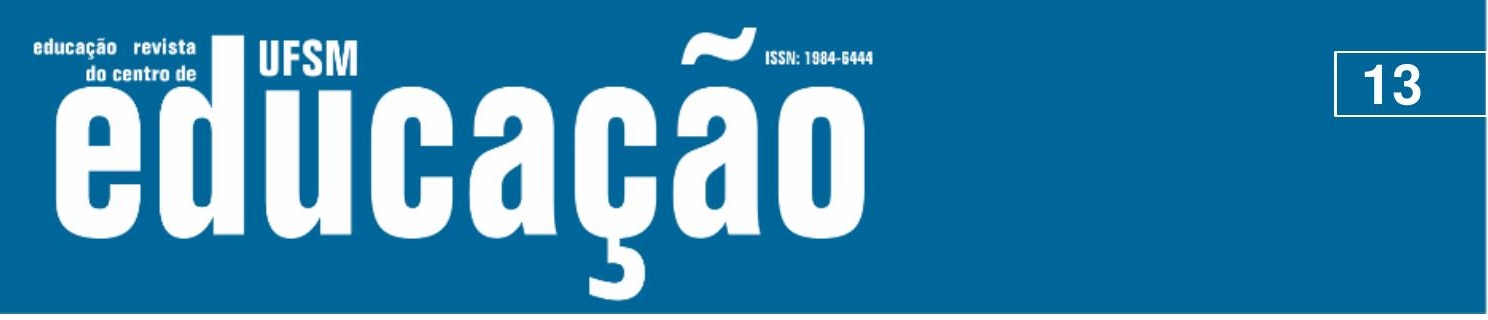

ISSN: 1984-6444 | http://dx.doi.org/10.5902/1984644466423

\section{References}

ANALYTICAL Center NAFI. Digital literacy of Russian teachers. Analytical Center NAFI, 2019. Available at: https://nafi.ru/projects/sotsialnoe-razvitie/tsifrovayagramotnost-rossiyskikh-pedagogov/. Accessed: 1 mar. 2021

ANDREW, Alison et al. Learning during the lockdown: Real-time data on children's experiences during home learning (IFS briefing note BN288). Institute for Fiscal Studies, 18 may 2020. Available at: https://ifs.org.uk/uploads/Edited_FinalBN288\%20Learning\%20during\%20the\%20lockdown.pdf. Accessed: 1 mar. 2021

BARAKHSANOVA, Elizaveta Afanasievna, et al. Peculiarities of quality management of teachers' e-learning training in the Arctic regions. Espacios, Caracas, v. 38, n. 55, p. 25, 2017.

BARAKHSANOVA, Elizaveta Afanasievna, et al. Current trends in digital education development in the Republic of Sakha (Yakutia). Espacios, Caracas, v. 40, n. 9, 2019. Available at: https://www.elibrary.ru/item.asp?id=38689142. Accessed: 1 mar. 2021

BARBER, Wendy; BLAYONE, Todd. Student perceptions of fully online flipped community learning: A case study progress in education. Progress in education, $n$. 53, p. 161-183, 2018. Available at: https://www.researchgate.net/publication/329217207_Student_Perceptions_of_Fully_ Online_Flipped_Community_Learning_A_Case_Study. Accessed: 1 mar. 2021

BATES, Tony. Teaching in a Digital Age. 2 ed. Vancouver: Tony Bates Associates Ltd, 2019. Available at: https://pressbooks.bccampus.ca/teachinginadigitalagev2/. Accessed: 1 mar. 2021

BLAYONE, Todd. Theorizing effective uses of digital technology with activity theory. Technology, Pedagogy and Education, v. 28, n. 4, p. 447-462, 2019. Available at: https://doi.org/10.1080/1475939X.2019.1645728. Accessed: 1 mar. 2021

CATTIK, Melih; ODLUYURT, Serhat. The effectiveness of the smart boardbased small-group graduated guidance instruction on digital gaming and observational learning skills of children with autism spectrum disorder. Turkish Online Journal of Educational Technology, Turkey, v. 16, n. 4, p. 84-102, oct. 2017. Available at: https://files.eric.ed.gov/fulltext/EJ1160646.pdf. Accessed: 1 mar. 2021

GREENHOW, Christine; LEWIN, Cathy; STAUDT WILLET, Bret, 2020 The educational response to Covid-19 across two countries: a critical examination of initial digital pedagogy adoption. Technology, Pedagogy and Education, v. 30, n. 1, p. 7-25, 2021. Available at: https://doi.org/10.1080/1475939X.2020.1866654. Accessed: 1 mar. 2021 


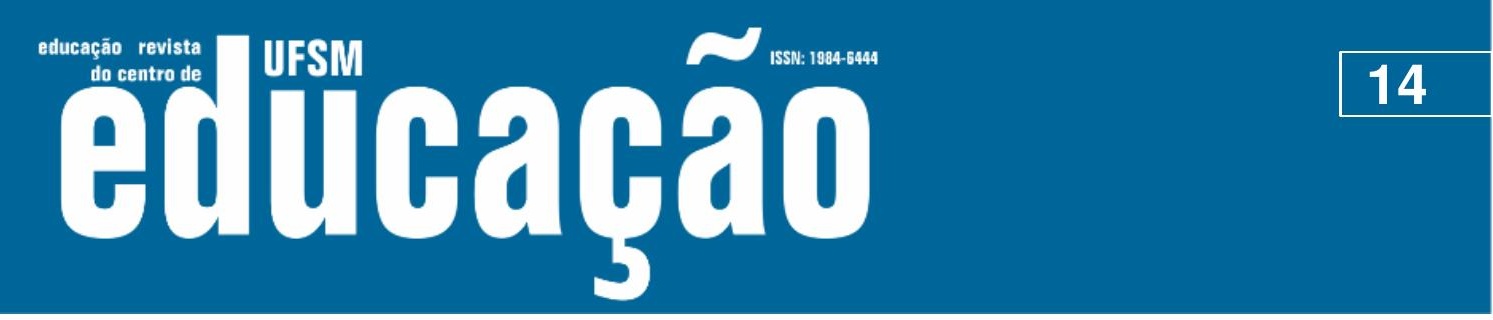

ISSN: 1984-6444 | http://dx.doi.org/10.5902/1984644466423

CLARK, Ruth Colvin; \& MAYER, Richard. E-learning and the science of instruction: Proven guidelines for consumers and designers of multimedia learning. Hoboken: John Wiley \& Sons, 2016. Available at: http://dx.doi.org/10.1002/9781119239086. Accessed: 1 mar. 2021

DE', Rahul; PANDEY, Neena; PAL, Abhipsa. Impact of digital surge during covid-19 pandemic: A viewpoint on research and practice. International Journal of Information Management, United Kingdom, n. 55, dec. 2020. Available at: http://dx.doi.org/10.1016/j.jinfomgt.2020.102171. Accessed: 1 mar. 2021

GAFUROVA, Natalia Vladimirovna; CHURILOVA, Elena Yurievna. Methods of information technologies teaching. Practicum: Handbook. Krasnoyarsk: Siberian Federal University, 2011.

GILSTER, Paul. Digital Literacy. New York: Wiley, 1997.

GORBUNOVA, Irina Borisovna. Music Computer Technologies in the Perspective of Digital Humanities, Arts, and Researches. Opcion, Zulia, v. 35, n. 24, p. 360-375, 2019.

GUSHCHINA, S. M. Forming teacher's digital competence in the area of developing digital education resources, 2017.

DELCKER, Jan; IFENTHALER, Dirk. Teachers' perspective on school development at German vocational schools during the Covid-19 pandemic, Technology, Pedagogy and Education, v. 30, n. 1, p. 125-139, 12 dec. 2020. Available at: http://dx.doi.org/10.1080/1475939X.2020.1857826. Accessed: 1 mar. 2021

KORNILOV, Yuri, et al. Different approaches to the development of online learning in higher education. Propositos y representaciones, Lima, v. 8, n. S3, p. e706, 2020. Available at: http://dx.doi.org/10.20511/pyr2020.v8nSPE3.706. Accessed: 1 mar. 2021

KOSTIKOVA, Natalia Anatolyevna, et al. The didactic potential of university electronic information and educational environment in the context of a pandemic. Propositos $\mathbf{y}$ representaciones, Lima, v. 8, n. S3, p. e707, 2020. Available at: http://dx.doi.org/10.20511/pyr2020.v8nSPE3.707. Accessed: 1 mar. 2021

LAPCHIK, Mikhail Pavlovich. Preparing pedagogical personnel under conditions of informatization of education: Handbook. Moscow: BINOM, 2013. Available at: http://znanium.com/catalog.php?bookinfo=485601. Accessed: 1 mar. 2021

MARTIN, Allan; MADIGAN, Dan. Digital Literacies for Learning. London: Facet Publishing, 2006. 


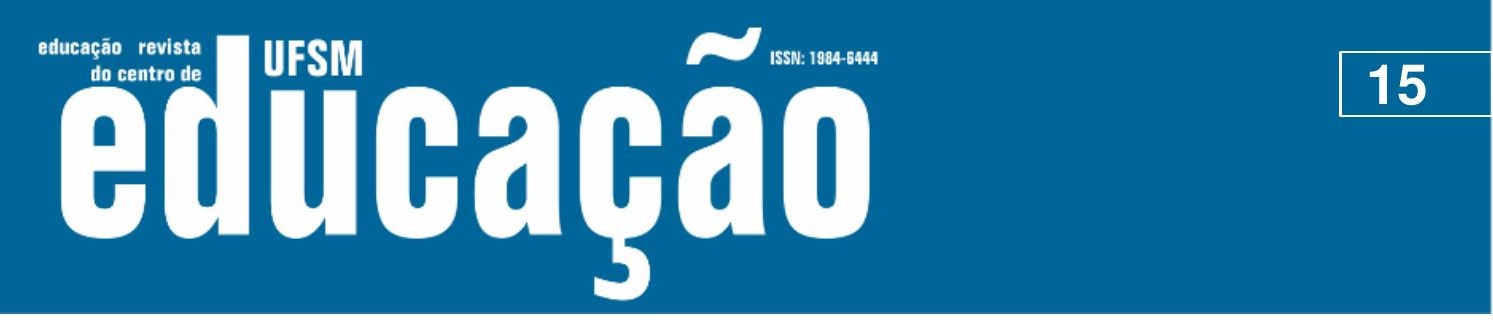

ISSN: 1984-6444 | http://dx.doi.org/10.5902/1984644466423

MAXWELL, Alec; JIANG, Zhaoshuo; CHEN, Cheng. Mobile learning for undergraduate course through interactive apps and a novel mobile remote shake table laboratory. In 2017 ASEE ANNUAL CONFERENCE AND EXPOSITION. Conference proceedings, v. 24. Columbus: American Society for Engineering Education, 2017. Available at: https://www.asee.org/public/conferences/78/papers/18403/view. Accessed: 1 mar. 2021

RUSSIAN FEDERATION. Ministry of Science and Higher Education. Modern Digital Educational Environment, 2021. Available at: http://neorusedu.ru/. Accessed: 1 mar. 2021

RUSSIAN FEDERATION. Government. National Program "Digital Economy of the Russian Federation", 2018. Available at: http://static.government.ru/media/files/9gFM4FHj4PsB79I5v7yLVuPgu4bvR7M0.pdf. Accessed: 1 mar. 2021

PROKOPIEV, Mikhail Semenovich, et al. Development of a programming course for students of a teacher training higher education institution using the programming language Python. Propositos y representaciones, Lima, v. 8, n. 3, 2020. Available at: https://www.elibrary.ru/item.asp?id=43856945. Accessed: 1 mar. 2021

QUARLES, Audrey McCrary et al. Integrating digital/mobile learning strategies with students in the classroom at the historical black college/university (HBCU). In: KEENGWE, Jared. Handbook of Research on Digital Content, Mobile Learning, and Technology Integration Models in Teacher Education. Grand Forks: University of North Dakota, 13 jul. 2017, p. 390-408.

SÁ, Maria Jose; SERPA, Sandro. The covid-19 pandemic as an opportunity to foster the sustainable Development of teaching in higher education. Sustainability, Basel, v. 12 , n. 20 , p. 1-16, 2020. Available at: http://dx.doi.org/10.3390/su12208525. Accessed: 1 mar. 2021

SOLDATOVA, G. U.; SHLYAPNIKOV, V. N. Digital competence of Russian pedagogues. Psychological science and education, Moscow, v. 20, n. 4, p. 5-18, 2015.

AGASISTI, Tommaso; SONCIN, Mara. Higher education in troubled times: on the impact of Covid-19 in Italy. Studies in Higher Education, v. 46, n. 1, p. 86-95, 2021. Available at: http://dx.doi.org/10.1080/03075079.2020.1859689. Accessed: 1 mar. 2021

TRETYAKOVA, Tatiana et al. A Digital education as a new vector of development of education in the northern regions. In INTEGRATING ENGINEERING EDUCATION AND HUMANITIES FOR GLOBAL INTERCULTURAL PERSPECTIVES. Lecture Notes in Networks and Systems, St.-Petersburg, p. 864-870, 2020. 


\section{usm

ISSN: 1984-6444 | http://dx.doi.org/10.5902/1984644466423

TRETYAKOVA, Tatiana et al. Distance pedagogical education in the conditions of the coronavirus. Propositos y representaciones, v. 8, n. S3, p. e718, 2020. Available at: http://dx.doi.org/10.20511/pyr2020.v8nSPE3.718. Accessed: 1 mar. 2021

VLASOVA, Elena Zotikovna et al. Effective adaptive training of students in Russian pedagogical universities to use e-learning technologies. Espacios, Caracas, v. 39, n. 23, p. 10, 2018.

VLASOVA, Elena Zotikovna et al. Teacher education in higher education systems during pandemic and the synergy of digital technology. Propositos $y$ representaciones, $\quad$ v. $8, \quad$ n. $S 3, \quad$ p. 719,2020 . Available at: http://dx.doi.org/10.20511/pyr2020.v8nSPE3.719. Accessed: 1 mar. 2021

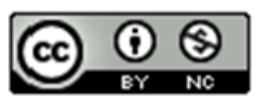

This work is licensed under a Creative Commons Attribution-NonCommercial 4.0 International (CC BY-NC 4.0) 